\title{
Frictional Characteristics of Brake Pad Materials Alternate to Asbestos
}

\author{
Kishor N. Hendre, Bhanudas D. Bachchhav, Harijan H. Bagchi
}

\begin{abstract}
Nevertheless, asbestos though having ample physical and tribo-mechanical properties is being banned worldwide due to its health hazardousness. Most importantly, any material replacing asbestos should have comparable friction properties. This paper aims at comparative study of frictional characteristics of asbestos base and asbestos free brake pad materials. A total of three friction materials namely AF-22 (metallic based), CL-3003 (fine brass based) and DM-6 (asbestos based) were compressed and moulded into a sample. Experiments were performed using dedicated test set-up based on Pin-on-disc principle. Coefficient of friction was compared for three materials at different conditions of sliding velocity and pressure. Experiments were performed using Taguchi's $L_{27}$ orthogonal array. Ranking of the parameters have been done based on experimental results and $S / N$ ratio analysis. The elemental composition of materials was measured by EDS technique. Scanning electron micrographs of brake pad samples were tested at different magnifications. Further investigations to evaluate wear rate, stopping distance under simulative test conditions are suggested.
\end{abstract}

Index Terms: Asbestos-free, Brake Pad Materials, Friction, Pin-on-Disc Test, Taguchi Method

\section{INTRODUCTION}

A brake pad plays very important role in automotive braking system to decelerate the vehicle. The friction between brake pads and rotating disc/drum causes to stop the vehicle. In order to achieve this brake friction material should maintain a high coefficient of friction, good thermal conductivity and hardly any running wear. Asbestos based friction materials have been used since long are being banned because of its carcinogenic nature. Efforts are being endorsed in developing organic friction materials having equally good tribo-mechanical properties to that of asbestos [1-7]. The basic elements of friction material usually are binders, reinforcements, friction modifiers and fillers; however their composition are subjected to applications, technological

Revised Manuscript Received on December 30, 2019.

* Correspondence Author

Kishor N. Hendre, PG Scholar, Department of Mechanical Engineering, All India Shri Shivaji Memorial Society's, College of Engineering, Pune, (Maharashtra) India. E-mail: kishorhendre77@gmail.com

Bhanudas D. Bachchhav, Prof. and Head, Department of Mechanical Engineering, All India Shri Shivaji Memorial Society's, College of Engineering, Pune, (Maharashtra) India. Corresponding Author E-mail: bdbachchhav@aissmscoe.com, bhanudas2k@gmail.com

Harijan H. Bagchi, Professor Emeritus, Department of Production Engineering and Industrial Management, College of Engineering, Pune, (Maharashtra) India. E-mail: hbagchi.prod@coep.ac.in

(C) The Authors. Published by Blue Eyes Intelligence Engineering and Sciences Publication (BEIESP). This is an open access article under the CC BY-NC-ND license (http://creativecommons.org/licenses/by-nc-nd/4.0/) developments and impending environmental impact. Development of alternate to asbestos friction materials from agro-waste $[1,4-5,15]$ composites $[8-9,11]$ and with no copper alloys and lead [2-3] have been conceded. Evaluation of mechanical and physical properties of alternate to asbestos friction materials with other commercial brake pad materials and their performance evaluation was discussed [1-5]. Matteo et. al. investigated on the use of the pin-on-disc test to simulate off-brake friction and wear characteristics of friction materials [11, 14] and reciprocating sliding test set-up [18-19]. Morphological analysis [13] , correlation among temperature variation [16-17] , tribological evaluation of rubber resin bonded brake pad materials [19] were examined for its commercial applicability. In order to rank critical properties for a selection of brake pad materials amongst all, an Analytic Hierarchy Process (AHP) was used by Bachchhav et. al., [7] and found that friction coefficient and thermal conductivity of material are most predominant properties considering qualitative attributes only; however further investigation is recommended considering quantitative variables.

In the present study, three friction materials namely AF-22 (metallic based), CL-3003 (fine brass based) and DM-6 (asbestos based) were considered for comparison of their tribological performance. In this paper the frictional characteristics of above materials were evaluated using pin-on-disc set up. Analysis of variance using Taguchi's technique was carried out in order to find suitability of a material for brake pad application.

\section{FRICTION MATERIALS}

\section{A. Brake Pad Friction Material}

Three friction materials were procured from CO-EFF friction bands, India under the trade names AF-22, CL-3003 and DM-6 with their mechanical and physical properties supplied in Table 1. AF-22 brake pad material made up of non-asbestos friction material, rubber resin bonded, metallic filler based. CL-3003 is made up of non-asbestos friction material with extremely high amount of organic and inorganic reinforcing fibre system, fine brass fibres, non-ferrous, organic binding system by special synthetic rubber modified resins plus NBR rubber. DM-6 is a commercially available asbestos fibre based brake pad material. It also includes organic binding system special formaldehyde resins used as binders. Brake friction material samples were crushed into the fine powder samples for energy dispersive spectroscopy (EDS) and scanning electron microscopy (SEM) analysis. 
The density, compressive strength and transverse bending strength are depicted in Table 1 . The percentage of each elemental were measured by EDS is reported in Table 2.

Table1. Brake Pad Materials and Their Properties

\begin{tabular}{|c|c|c|c|}
\hline Materials & $\begin{array}{l}\text { Density } \\
\left(\mathrm{g} / \mathrm{cm}^{3}\right)\end{array}$ & $\begin{array}{c}\text { Compressive } \\
\text { Strength } \\
\left(\mathrm{N} / \mathbf{m m}^{2}\right)\end{array}$ & $\begin{array}{c}\text { Transverse } \\
\text { Bending Strength } \\
\left(\mathrm{N} / \mathrm{mm}^{2}\right)\end{array}$ \\
\hline AF-22 & 2.12 & 165 & 78 \\
\hline CL-3003 & 1.90 & 190 & 85 \\
\hline DM-6 & 1.78 & 133 & 47 \\
\hline
\end{tabular}

Table2. Elemental Composition as per EDS for Brake Friction Material

\begin{tabular}{cccc}
\hline lements & $\begin{array}{c}\text { AF-22 } \\
\text { [wt. \%] }\end{array}$ & $\begin{array}{c}\text { CL-3003 } \\
\text { [wt. \%] }\end{array}$ & $\begin{array}{c}\text { DM-6 } \\
\text { [wt. \%] }\end{array}$ \\
\hline $\mathrm{C}$ & 31.70 & 37.77 & 15.45 \\
$\mathrm{O}$ & 27.72 & 32.19 & 44.74 \\
$\mathrm{Si}$ & 12.74 & 12.67 & 19.42 \\
$\mathrm{Ba}$ & 7.57 & 0.00 & 0.00 \\
$\mathrm{Sb}$ & 6.79 & 4.16 & 0.00 \\
$\mathrm{Ca}$ & 6.68 & 2.92 & 0.00 \\
$\mathrm{Mo}$ & 3.59 & 5.00 & 0.30 \\
$\mathrm{Al}$ & 2.09 & 3.51 & 0.23 \\
$\mathrm{Mg}$ & 1.11 & 1.46 & 19.12 \\
$\mathrm{Na}$ & 0.00 & 0.31 & 0.13 \\
$\mathrm{Fe}$ & 0.00 & 0.00 & 0.62 \\
\hline
\end{tabular}

Figure 1 shows EDS spectrum and elementals of AF-22 material. It contains ingredients like $\mathrm{C}, \mathrm{O}, \mathrm{Au}, \mathrm{Si}, \mathrm{Ba}, \mathrm{Sb}, \mathrm{Ca}$, $\mathrm{Mo}, \mathrm{Al}$ etc.

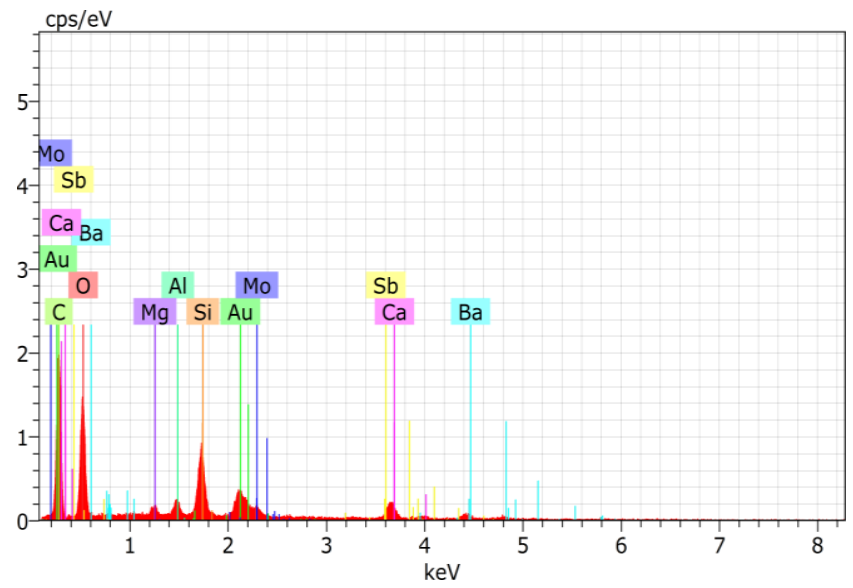

Fig. 1.EDS Spectrum as Detected for AF-22 Brake Pad Material Sample

Figure 2 shows EDS spectrum and elemental composition of CL-3003 material. It shows ingredients like C, Si, Mo, Sb, $\mathrm{Al}, \mathrm{Ca}, \mathrm{Mg}$ etc.

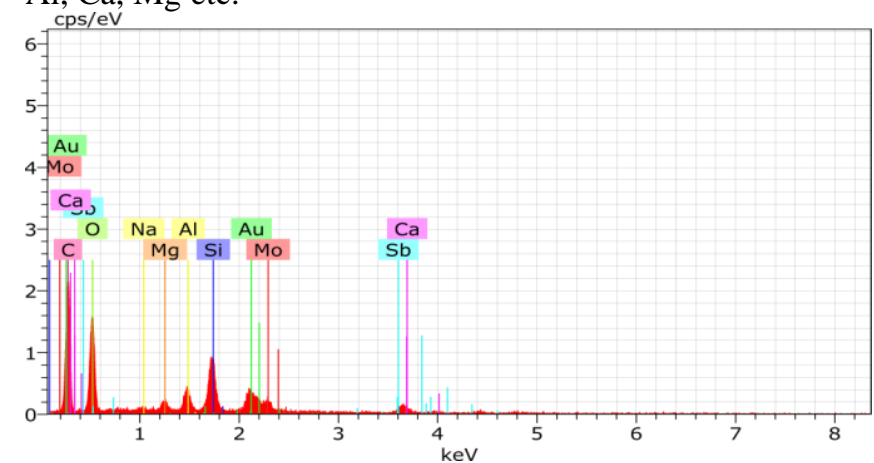

Fig.2. EDS Spectrum as Detected for CL-3003 Brake Pad Material Sample

Retrieval Number: B3170129219/2019@BEIESP DOI: 10.35940/ijeat.B3170.129219

Journal Website: www ijeat org
Figure 3 shows EDS spectrum and elemental composition of DM-6 material. It shows ingredients like Si, Mg, C, Fe, Mo, $\mathrm{Na}$, etc.

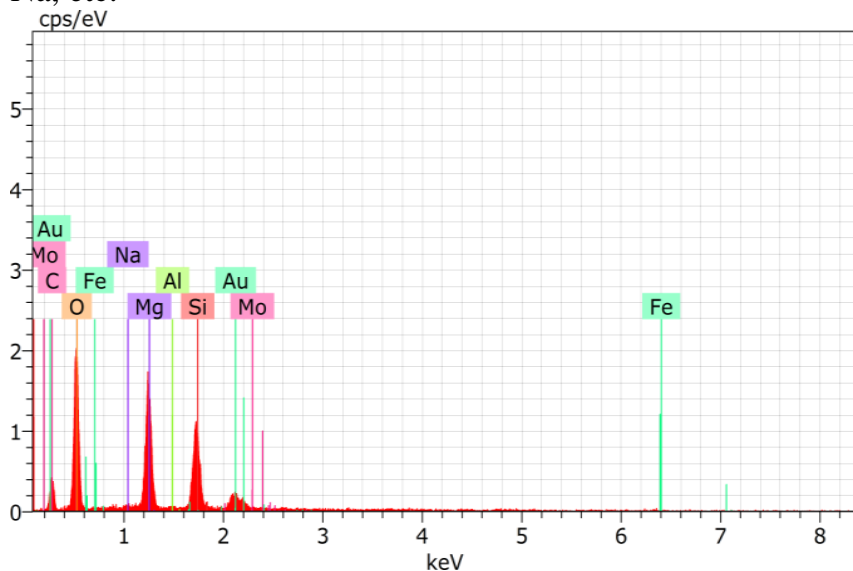

Fig.3. EDS Spectrum as Detected for DM-6 Brake Pad Material Sample

\section{B. AF-22 Friction Material}

Scanning Electron Microscope images were taken at $50000 \mathrm{x}$ and $2000 \mathrm{x}$ magnifications. At $50000 \mathrm{x}$ magnification it shows chunk, segments and block images of AF-22 compound (Figure 4a). Due to higher weight percentage of rubber resin, C (Carbon) and $\mathrm{Si}$ (Silicon) provides hydrocarbon close fit bonding for higher strength. At $2000 \mathrm{x}$ magnification brittle and flaky images due to presence of Ca and $\mathrm{Sb}$ as in Figure 4b. It also includes elemental properties of $\mathrm{Ba}$ (Barium), Sb (Antimony), Ca (Calcium) and Mo (Molybdenum).

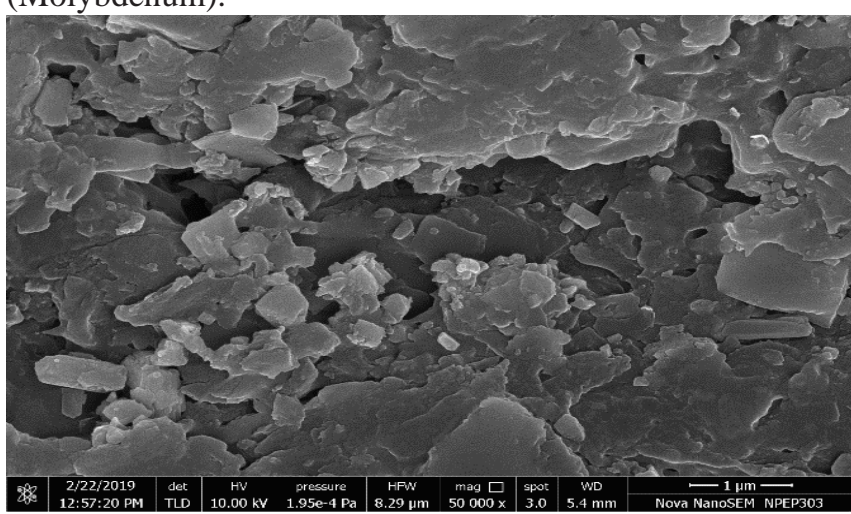

Fig.4a. SEM Image of AF-22 Brake Material Sample at 50000 x Magnification

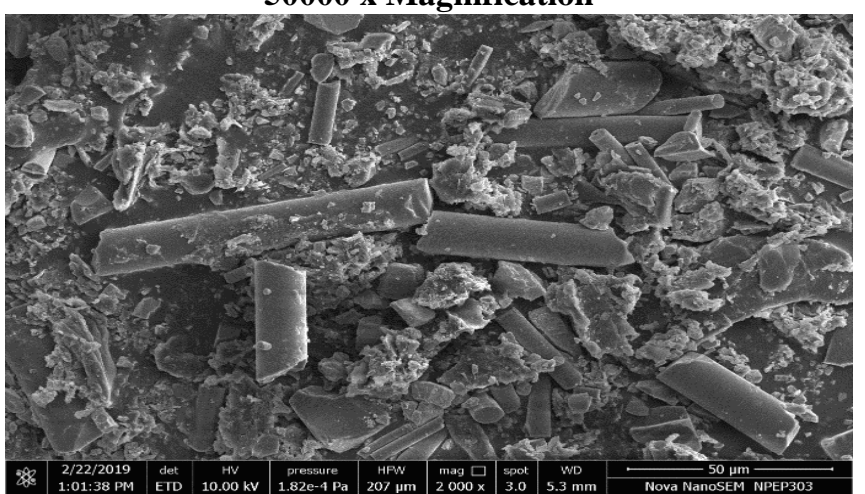

Fig.4b. SEM Image of AF-22 Brake Material Sample at 2000 x Magnification

Published By: Blue Eyes Intelligence Engineering \& Sciences Publication 


\section{CL-3003 Friction Material}

The SEM characterization measure the segmental sections of CL-3003 as shown in Figure 5a and 5b. Where from EDS plots it can be inferred that, as the concentration increases $\mathrm{C}$ (Carbon) and Si (Silicon) wt \% content increases due to the high cross linkage of organic (hydrocarbon chain of rubber) fiber material. Elemental raw $\mathrm{Si}$ and its intermetallic compounds are semiconductors and used as alloy integrals to provide more resistance to the aluminum, magnesium and other metals. Metallurgic silicon with 98-99 \% purity with Mo (Molybdenum) enhances harden-ability, toughness of steel and improves strength.

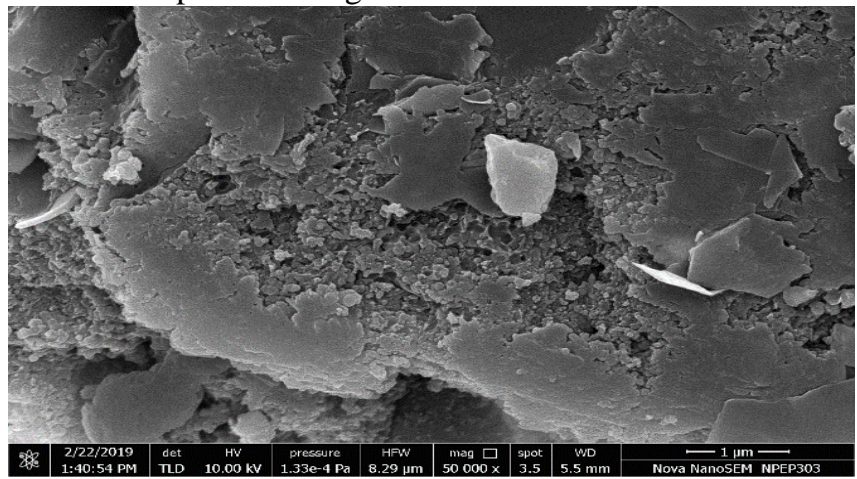

Fig.5a. SEM Image of CL-3003 Brake Pad Material Sample at $50000 \times$ Magnification

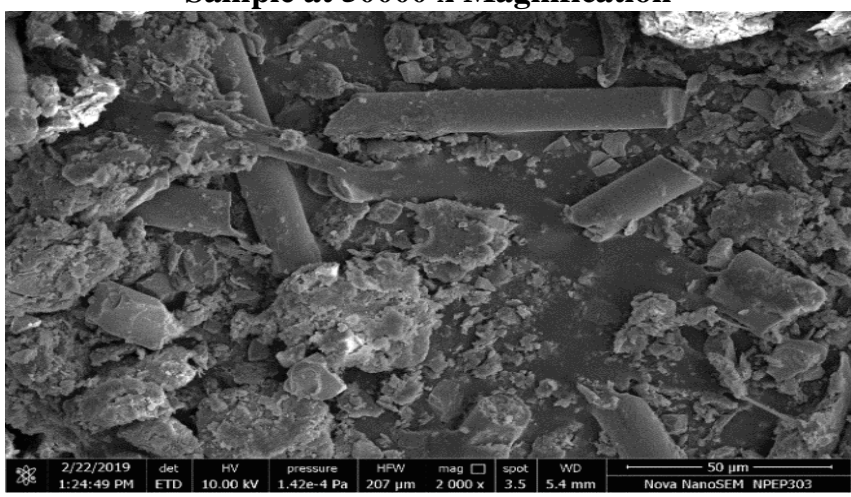

Fig.5b. SEM Image of CL-3003 Brake Pad Material Sample at $2000 \times$ Magnification

\section{DM-6 Friction Material}

SEM images in Figure 6a and 6b showing fibrous swirl of asbestos material. Elements like $\mathrm{Si}$ (Silicon), $\mathrm{Mg}$ (Magnesium), C (Carbon), Fe (Iron) which is a major composition of asbestos. Due to the presence of organic binder Formaldehyde resins, a synthetic polymer, C (Carbon) wt $\%$ is less.

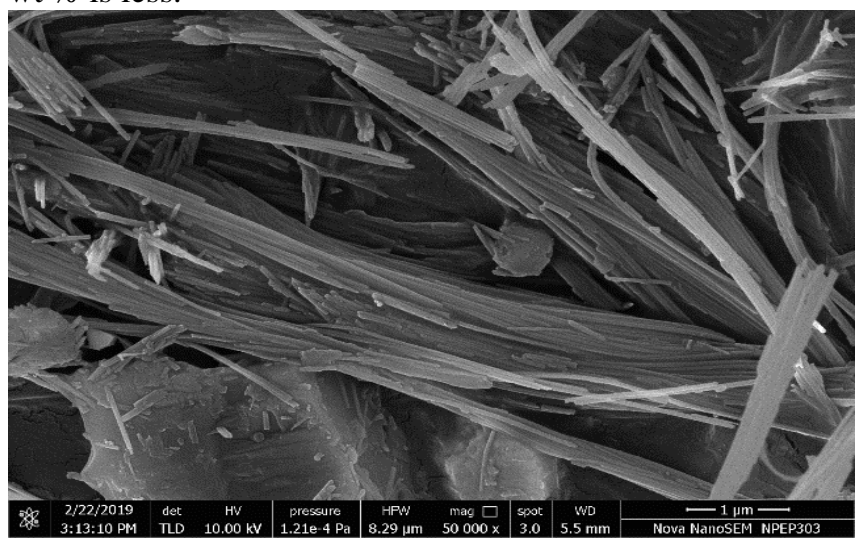

Fig.6a. SEM Image of DM-6 Brake Pad Material Sample at $50000 \times$ Magnification

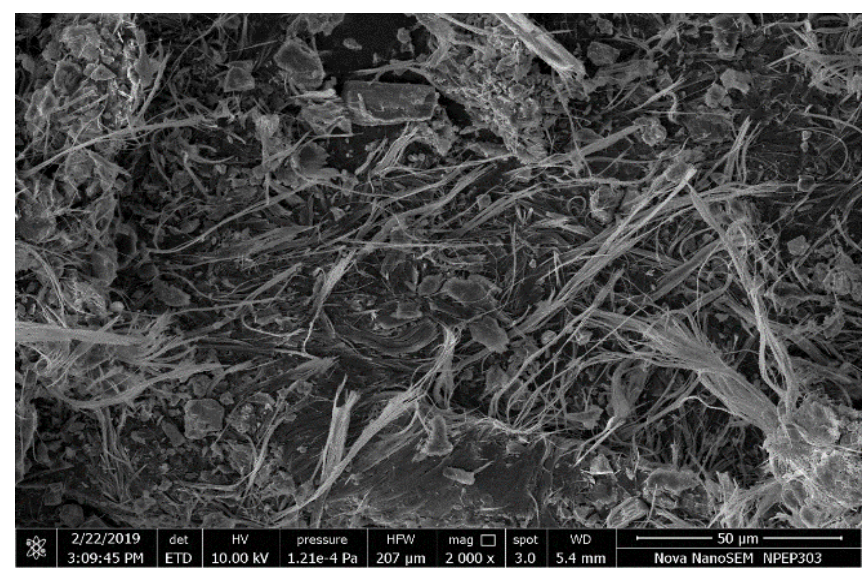

Fig.6b. SEM Image of DM-6 Brake Pad Material Sample at $2000 \times$ Magnification

\section{EXPERIMENTAL PROCEDURE}

DUCOM (TR-20LE) "Pin-on-disc" test set-up were used for experimentation. A schematic diagram for pin-on-disc set-up shown in Figure 7.

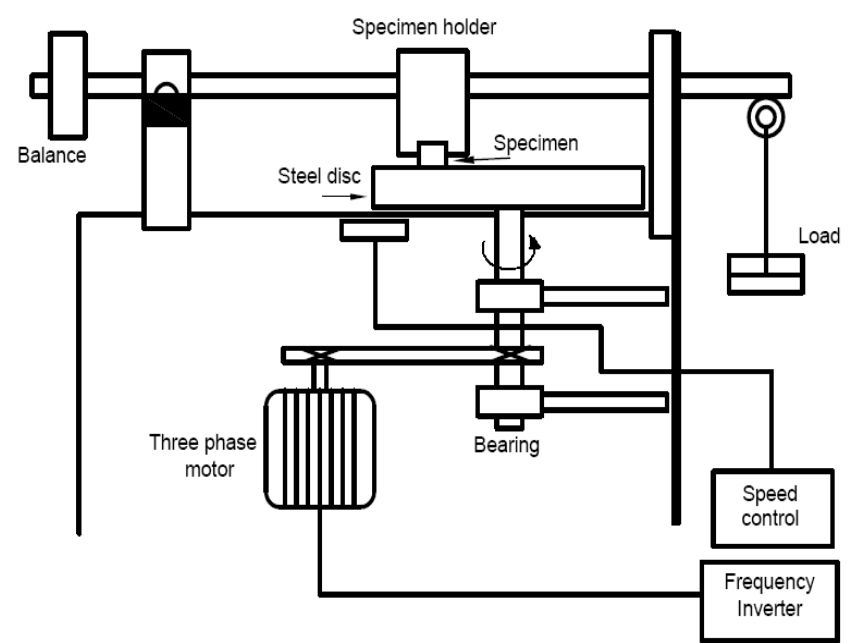

Fig.7. Schematic Diagram of Pin on Disc Set-Up

Sample pins of 8-mm diameter, each for AF-22, CL-3003and DM-6 were machined. The bottom surface of the pin is ensured to be perfectly flat so that entire surface will be in contact during experimentation. The disc of EN-31 material having diameter and thickness $160 \mathrm{~mm}$ and $10 \mathrm{~mm}$ respectively is hardened to $60 \mathrm{HRC}$ and ground on surface grinding machine. The disc is rotating through a driven spindle, a lever arm device with jaws to hold the pin sample is allowed to be forced against the revolving disc. A controlled load ia attached through a wire rope. The tangential force exerted by the disc on the pin is measured by the beam-type load cell. The sliding speed and pressure were varied for specific period of time in order to evaluate the friction coefficient.

\section{A. Plan of Experiments}

Taguchi's $\mathrm{L}_{27}$ orthogonal array was used for three factors at three levels. Table 3 shows the variables and their corresponding levels.

Published By:

Blue Eyes Intelligence Engineering \& Sciences Publication

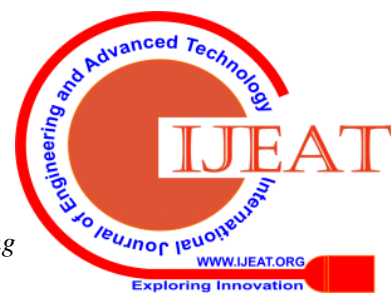


Table 3.Assignment of the Levels to the Factors

\begin{tabular}{cccc}
\hline \multicolumn{4}{c}{ Levels } \\
\hline Factors & 1 & 2 & 3 \\
Materials & AF-22 & CL-3003 & DM-6 \\
Pressure $\left(\mathrm{N} / \mathrm{mm}^{2}\right)$ & 1 & 2 & 3 \\
Sliding Velocity $(\mathrm{m} / \mathrm{s})$ & 1.05 & 3.15 & 5.25 \\
\hline
\end{tabular}

Table 4 shows $\mathrm{L}_{27}\left(3^{13}\right)$ array and output response studied as coefficient of friction $(\mu)$. Two replicates were taken for more accuracy.

Table4. Experimental Results

\begin{tabular}{|c|c|c|c|c|c|c|}
\hline Run & Material & $\begin{array}{l}\text { Pressure } \\
\left(\mathrm{N} / \mathbf{m m}^{2}\right)\end{array}$ & $\begin{array}{c}\text { Sliding } \\
\text { Velocity } \\
\text { (m/s) }\end{array}$ & $\begin{array}{c}\mathrm{COF} \\
\mu_{1}\end{array}$ & $\underset{\mu_{2}}{\text { COF }}$ & $\begin{array}{c}\text { S/N } \\
\text { Ratio }\end{array}$ \\
\hline 1 & AF-22 & 1 & 1.05 & 0.33 & 0.32 & -9.76 \\
\hline 2 & AF-22 & 1 & 3.15 & 0.29 & 0.29 & -10.75 \\
\hline 3 & AF-22 & 1 & 5.25 & 0.27 & 0.27 & -11.37 \\
\hline 4 & AF-22 & 2 & 1.05 & 0.34 & 0.34 & -9.37 \\
\hline 5 & AF-22 & 2 & 3.15 & 0.31 & 0.32 & -10.03 \\
\hline 6 & AF-22 & 2 & 5.25 & 0.28 & 0.28 & -11.05 \\
\hline 7 & AF-22 & 3 & 1.05 & 0.37 & 0.37 & -8.63 \\
\hline 8 & AF-22 & 3 & 3.15 & 0.34 & 0.35 & -9.24 \\
\hline 9 & AF-22 & 3 & 5.25 & 0.32 & 0.32 & -9.89 \\
\hline 10 & CL-3003 & 1 & 1.05 & 0.36 & 0.36 & -8.87 \\
\hline 11 & CL-3003 & 1 & 3.15 & 0.33 & 0.32 & -9.76 \\
\hline 12 & CL-3003 & 1 & 5.25 & 0.31 & 0.31 & -10.17 \\
\hline 13 & CL-3003 & 2 & 1.05 & 0.37 & 0.38 & -8.52 \\
\hline 14 & CL-3003 & 2 & 3.15 & 0.34 & 0.34 & -9.37 \\
\hline 15 & CL-3003 & 2 & 5.25 & 0.32 & 0.32 & -9.89 \\
\hline 16 & CL-3003 & 3 & 1.05 & 0.38 & 0.38 & -8.40 \\
\hline 17 & CL-3003 & 3 & 3.15 & 0.35 & 0.36 & -8.99 \\
\hline 18 & CL-3003 & 3 & 5.25 & 0.33 & 0.33 & -9.62 \\
\hline 19 & DM-6 & 1 & 1.05 & 0.38 & 0.38 & -8.40 \\
\hline 20 & DM-6 & 1 & 3.15 & 0.36 & 0.36 & -8.87 \\
\hline 21 & DM-6 & 1 & 5.25 & 0.34 & 0.34 & -9.37 \\
\hline 22 & DM-6 & 2 & 1.05 & 0.39 & 0.40 & -8.07 \\
\hline 23 & DM-6 & 2 & 3.15 & 0.37 & 0.37 & -8.63 \\
\hline 24 & DM-6 & 2 & 5.25 & 0.35 & 0.35 & -9.11 \\
\hline 25 & DM-6 & 3 & 1.05 & 0.39 & 0.42 & -7.86 \\
\hline 26 & DM-6 & 3 & 3.15 & 0.38 & 0.38 & -8.40 \\
\hline 27 & DM-6 & 3 & 5.25 & 0.37 & 0.37 & -8.63 \\
\hline
\end{tabular}

In Figure 8 graph plotted coefficient of friction vs time AF-22, CL-3003, DM-6 brake pad material.

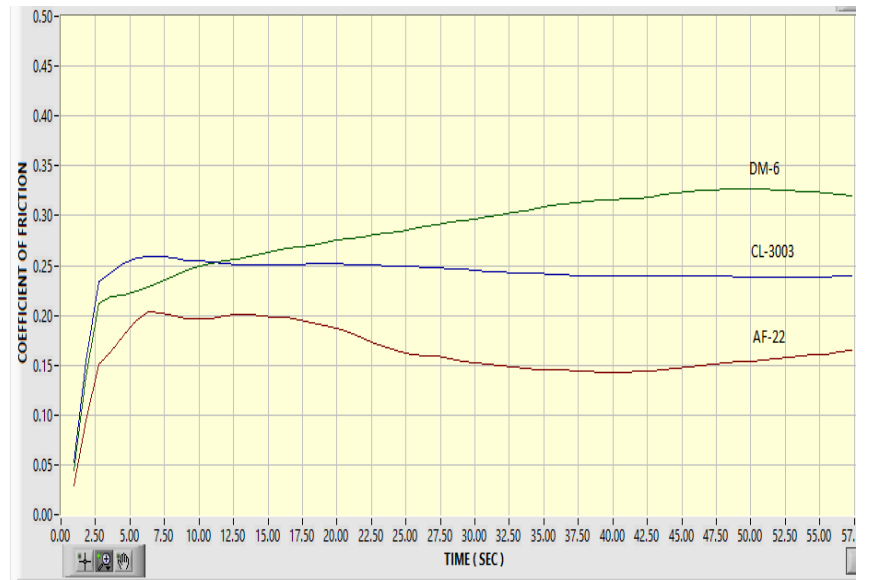

Fig.8. Graph of Coefficient of Friction vs Time for Braking Materials.

Total 54 readings were taken, to allow the analysis of the variance of the result and $\mathrm{S} / \mathrm{N}$ ratios. Response table for $\mathrm{S} / \mathrm{N}$ ratios is depicted in (Table 5).
Table 5. Response Table for S/N Ratio

\begin{tabular}{cccc}
\hline Level & Material & Pressure & $\begin{array}{c}\text { Sliding } \\
\text { Velocity }\end{array}$ \\
\hline 1 & -10.015 & -9.706 & -8.657 \\
2 & -9.293 & -9.342 & -9.343 \\
3 & -8.598 & -8.858 & -9.906 \\
Delta & 1.417 & 0.848 & 1.248 \\
\hline Rank & $\mathbf{1}$ & $\mathbf{3}$ & $\mathbf{2}$ \\
\hline
\end{tabular}

\section{DATA ANALYSIS AND DISCUSSION}

Preliminary experiments conducted with the aim of relating the influence of material, pressure and sliding velocity with the coefficient of friction $(\mu)$ and ranking them based on their percentage contribution.

\section{A. Main Effect Plot for S/N Ratio}

For brake pad application friction is desirable hence main effect plot for signal to noise ratio were plotted considering larger is better as an objective function as shown in Figure 9.

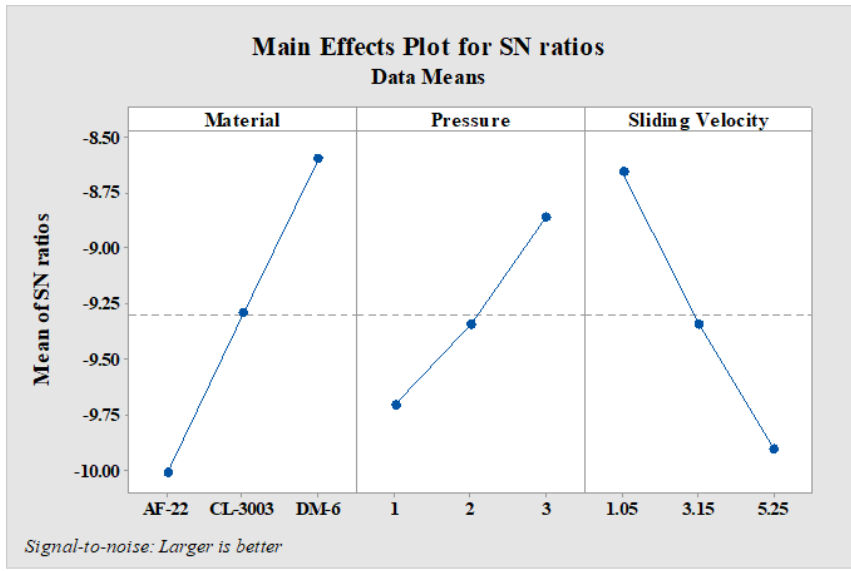

Fig.9. Main Effect Plot for SN Ratio

\section{B. Analysis of Variance andS/N Ratio}

The $\mathrm{S} / \mathrm{N}$ ratio gives the spread around a mean value. The larger the ratio, the smaller the spread. Mean square deviation (MSD) and S/N ratios were calculated using equation (1) and (2) as given below.

$$
\mathrm{S} / \mathrm{N}=-10_{\log }(\mathrm{MSD})
$$

Where MSD = mean square deviation. For larger is better:

$$
\text { MSD }=\left(\mathrm{y}_{1}{ }^{2}+\mathrm{y}_{2}{ }^{2}+\mathrm{y}_{3}{ }^{2}+-----\mathrm{y}_{\mathrm{n}}{ }^{2}\right) / \mathrm{n}
$$

Where $n$ is the number of observations and $y$ is the output response.

Table6. ANOVA for Coefficient of Friction $(\mu)$

\begin{tabular}{ccccccc} 
Source & DF & Seq SS & $\begin{array}{c}\text { Adj } \\
\text { MS }\end{array}$ & F-Value & P-Value & $\begin{array}{c}\text { Cont. } \\
(\%)\end{array}$ \\
\hline Material & 2 & 0.006797 & 0.00339 & 127.10 & 0.000 & $\mathbf{4 2 . 9 2}$ \\
Pressure & 2 & 0.002830 & 0.00141 & 52.92 & 0.000 & $\mathbf{1 7 . 8 7}$ \\
Sliding & 2 & 0.005674 & 0.00283 & 106.12 & 0.000 & $\mathbf{3 5 . 8 3}$ \\
$\begin{array}{l}\text { Velocity } \\
\text { Error }\end{array}$ & 20 & 0.000535 & 0.00002 & & & $\mathbf{3 . 3 8}$ \\
Total & 26 & 0.015836 & & & & $\mathbf{1 0 0 . 0 0}$ \\
\hline
\end{tabular}


$\mathrm{S} / \mathrm{N}$ ratios for coefficient of friction, ranking of parameters and analysis of variance were done using MINITAB, Taguchi design software and shown in Table 5 and 6 respectively. Based on pure sum of squares percentage contribution of each variable were calculated.

\section{CONCLUSION}

Pin on disc tribo-tester were used to study and compare friction coefficient of two non asbestos verses asbestos based brake pad materials under dry sliding contact conditions. The EDS spectrum represents the elemental analysis of three different materials. Scanning electron microscopy images depicted chunk, segments and block images for both non-asbestos materials, however fibrous swirl were observed in asbestos material indicating less effective against tribological properties.

Friction coefficient were observed in the range of 0.25 to 0.45 for all materials under consideration; however, friction in case of DM 6 was marginally higher than other two materials viz. AF 22 and CL 3003. The coefficient of friction under dry sliding condition increased with pressure but decreased with sliding velocity for all three materials.

Taguchi's analysis method has enabled to analyse an effect of material, pressure and sliding velocity on friction coefficient in three different brake pad materials. Ranking of the parameters have been done and it was found that brake material contributes largely (42.92 \%) followed by sliding velocity (35.83 \%), pressure (17.87 \%) and have statistical significance on friction in brake pad application.

However, detail research necessitates involving appropriate material to evaluate thermal stability, wear rate and stopping distance using simulative test conditions. Also the commercial uses of such materials for specific braking operations are to be predicted.

\section{ACKNOWLEDGMENT}

The author/s thankfully acknowledge(s) the financial support provided by The Institution of Engineers (India) for carrying out Research \& Development work in this subject.

\section{REFERENCES}

1. O. A. Ibhadode, I. M. Dagwa, "Development of asbestos-free friction lining material from palm kernel shell", Journal of the Braz. Soc. of Mech. Sci. and Engg, vol. 2, pp. 166-173, 2008.

2. Rongping Yun, Peter Filip, Yafei Lu, "Performance and evaluation of eco-friendly brake friction materials", Tribology International, vol. 43, pp. 2010-2019, 2010.

3. Aranganathan N., Jayashree Bijwe, "Development of copper-free eco-friendly brake-friction material using novel ingredients", Wear, vol. 352, no. 353, pp. 79-91, 2016.

4. Dinesh Shinde, K. N. Mistry, "Asbestos base and asbestos free brake lining materials: comparative study", World Scientific News, vol. 61, no. 2, pp. 192-198, 2017.

5. Vishal Mahale, Jayashree Bijwe, Sujeet Sinha, "Influence of nano-potassium titanate particle on the performance of NAO brake-pad", Wear, vol. 376, no. 377, pp. 727-737, 2017.

6. Dayang Nor Fatin Mahmud, Mohd Fadzli Bin Abdollah, Nor Azmmi Bin Masripan, Noreffendy Tamaldin, Hilmi Amiruddin, "Influence of contact pressure and sliding speed dependence on the tribological characteristics of an activated carbon epoxy composite derived from palm kernel under dry sliding conditions", Friction, vol. 7, no. 3, pp. 227-236, 2019.

7. Hendre K. N., Bachchhav B. D., "Critical property assessment of novel brake pad materials by AHP", Journal of Manufacturing Engineering, vol. 13, no. 3, pp. 148-151, 2018.
8. Johnson O. Agunsoye, Sefiu A. Bello, Adeola A. Bamigbaiye, Kayode A. Odunmosu, Isaac O. Akinboye, "Recycled ceramic composite for automobile brake pad application", Journal of Research in Physics, vol. 39, no. 1, pp. 35-46, 2018.

9. Oluwatoyin Joseph Gbadeyan, Krishnan Kanny, "Tribological behaviors of polymer-based hybrid nanocomposite brake pad", Journal of Tribology, vol. 140, no. 032003, pp. 1-7, 2018.

10. H. P. Khairnar, V. M. Phalle, S. S. Mantha, "Estimation of automotive brake drum shoe interface friction coefficient under varying conditions of longitudinal forces using simulink", Friction, vol. 3, no. 3, pp. 214-227, 2015.

11. Cinzia Menapace, Mara Leonardi, Guido Perricone, Mauro Bortolotti, Giovanni Straffelini, Stefano Gialanella, "Pin-on-disc study of brake friction materials with ball-milled nanostructured components", Materials and Design, vol. 115, pp. 287-298, 2017.

12. F. Wang, K. K. Gu, W. J. Wang, Q. Y. Liu, M. H. Zhu, "Study on braking tribology behaviors of brake shoe material under the wet condition", Wear, vol. 342, no. 343, pp. 262-269, 2015.

13. L. Y. Barros, P. D. Neis, N. F. Ferreira, R. P. Pavlak, D. Masotti, L. T. Matozo, J. Sukumaran, P. De Baets, M. Ando, "Morphological analysis of pad-disc system during braking operations", Wear, vol. 352 , no. 353 , pp. 112-121, 2016.

14. Matteo Federici, Stefano Gialanella, Mara Leonardi, Guido Perricone, Giovanni Straffelini, "A preliminary investigation on the use of the pin-on-disc test to simulate off-brake friction and wear characteristics of friction materials", Wear, vol. 410, no. 411, pp. 202-209, 2018.

15. M. Polanjar, M. Kalin, I. Thorbjornsson, J. T. Thorgrimsson, N. Valle, A. Botor-Probierz, "Friction and wear performance of functionally graded ductile iron for brake pads", Wear, vol. 383, no. 383, pp. 85-94, 2017

16. N. S. M. EL-Tayeb, K. W. Liew, "On the dry and wet sliding performance of potentially new frictional brake pad materials for automotive industry”, Wear, vol. 266, pp. 275-287, 2009.

17. W. Osterle, C. Deutsch, T. Gradt, G. Orts-Gil, T. Schneider, A. I. Dmitriev, "Tribological screening tests for the selection of raw materials for automotive brake pad formulations", Tribology International, vol. 73, pp. 148-155, 2014.

18. Y. Lyu, J. Wahlstrom, M. Tu, U. Olofsson, "A friction, wear and emission tribometer study of non-asbestos organic pins sliding against AlSiC MMC discs", Tribology in Industry, vol. 40, no. 2, pp. 274-282, 2018.

19. Kishor N. Hendre, Bhanudas D. Bachchhav., "Friction and Wear Characteristics of Rubber Resin-Bonded Metallic Brake Pad Materials", International Journal of Engineering and Advanced Technology (IJEAT), Vol: 8, Issue: 6, pp. 1312-1316, 2019.

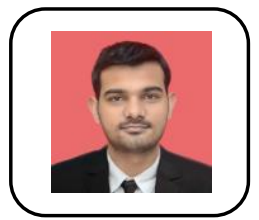

\section{AUTHORS PROFILE}

Kishor N. Hendreis a Post Graduate Scholar (Automotive Engineering) at the Department of Mechanical Engineering at All India Shri Shivaji Memorial Society's, College of Engineering, Pune. He is currently working on the project,

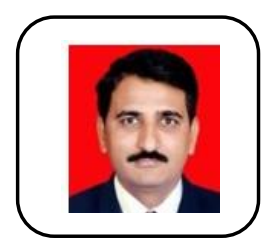

Dr. Bhanudas D. Bachchhav is currently working as a Professor and Head, Department of Mechanical Engineering, All India Shri Shivaji Memorial Society's, College of Engineering, Pune. $\mathrm{He}$ is having 18 years of teaching and research experience. He has more than 25 publications in various national and international journals. He has completed three research projects funded by Savitribai Phule Pune University. His area of research is Manufacturing Engineering, Tribology and Metal forming processes.

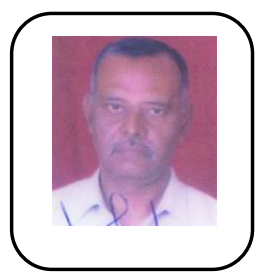

Dr. Harijan H. Bagchi is currently working as a Professor Emeritus at Department of Production Engineering and Industrial Management at College of Engineering, Pune. He has 30 years of research experience in the field of design and tribology in one of the national laboratories under Government of India. He has 18 years of teaching experience. 